\title{
IS BRAIN BANKING OF PSYCHIATRIC CASES VALUABLE FOR NEUROBIOLOGICAL RESEARCH?
}

\author{
Andrea Schmitt, Eleni Parlapani, Manfred Bauer, Helmut Heinsen, Peter \\ Falkai
}

\begin{abstract}
Schmitt A, Parlapani E, Bauer M, Heinsen H, Falkai P. Is brain banking of psychiatric cases valuable for neurobiological research? Clinics. 2008;63:255-66.

It is widely accepted that neurobiological abnormalities underlie the symptoms of psychiatric disorders such as schizophrenia and unipolar or bipolar affective disorders. New molecular methods, computer-assisted quantification techniques and neurobiological investigation methods that can be applied to the human brain are all used in post-mortem investigations of psychiatric disorders. The following article describes modern quantitative methods and recent post-mortem findings in schizophrenia and affective disorders. Using our brain bank as an example, necessary considerations of modern brain banking are addressed such as ethical considerations, clinical work-up, preparation techniques and the organization of a brain bank, the value of modern brain banking for investigations of psychiatric disorders is summarized.
\end{abstract}

KEYWORDS: Brain Banking. Post Mortem. Schizophrenia. Bipolar Disorder. Neurobiology.

\section{INTRODUCTION}

There is currently a high demand for neuropsychiatric brain banks to support neurobiological research with post-mortem tissue obtained from psychiatric patients with schizophrenia, bipolar disorder and depression. Based on a comprehensive literature search, we identified brain regions such as the hippocampus, prefrontal cortex and other heteromodal association cortices, which are presumably involved in the pathophysiology of psychiatric disorders. These investigations included functional and structural MRI studies as well as post-mortem studies of patients with schizophrenia and depression ${ }^{1,2}$, which pointed to neuronal regions and networks affected in psychiatric disorders. Modern structural and molecular biology techniques in post-mortem tissue allow for the identification of the affected regions. Moreover, these approaches reveal alterations on the cellular and molecular level, such as a decreased number or volume of

Department of Psychiatry, University of Goettingen - Germany. aschmit@gwdg.de

Received for publication on $06 / 02 / 08$

Accepted for publication on $07 / 02 / 08$ different cell types (neurons and glial cells), and alterations of pathway-related genes and proteins. Since the brain tissue consists of heterogenous cell types, further post-mortem investigations should differentiate between molecular alterations in different cell populations in order to define more specific pathophysiological hypotheses. The psychiatric brain bank in Goettingen, Germany organized by Brain Net Europe II (www.brainnet-europe.org) may serve as an example for brain bank organization, even though brain banks in other countries will have to comply with the requirements of their own national legal and ethical framework.

In Europe, the Netherlands brain bank represents one such prospective collection of brain tissue from patients with psychiatric disorders. ${ }^{3,4}$ In Germany, the Brain Net provides researchers with brain tissue of psychiatric patients from several centers. ${ }^{5}$ The University of Magdeburg, for example, stores a collection of serially cut paraffin embedded and fresh frozen tissue samples from patients with schizophrenia and affective disorders, which facilitate stereology as well as gene and protein expression studies. ${ }^{6,7}$ Funded by the European Commission, Brainnet Europe II provides formalinfixed and frozen brain tissue blocks from patients with Alzheimer's disease, Parkinson's disease, motoneuron disease, 
prion diseases, multiple sclerosis, schizophrenia (brain bank Goettingen) and affective disorders. ${ }^{1,8}$ Examples of well run, large scale neuropsychiatric brain banks in the USA that ship tissue to many centers include the Stanley Foundation brain collection, which provides paraffin-embedded and frozen brain tissue blocks, and the Harvard Brain tissue resource center, comprising schizophrenic, major depressive and bipolar cases. ${ }^{9-11}$ The Mount Sinai School of Medicine Medical Center Brain Bank provides a large collection of fixed and frozen tissue from elderly schizophrenic patients, ${ }^{12}$ and the Autism brain tissue bank is collecting rare tissue from children and adults with autism. ${ }^{13}$ In Brazil, there is a large brain bank situated in Sao Paulo. ${ }^{14}$ All these brain banks fulfill the modern criteria of brain banking such as ethical standards, proper collection of clinical data, and neuropathological investigations.

Early studies of histological abnormalities in the brains of schizophrenia patients revealed focal demyelination, neuronal atrophy, metachromatic bodies and lacunae. However, fixation and staining techniques were not standardized and the analysis was only qualitative, as techniques for quantification were lacking. ${ }^{15-17}$ Accordingly, further studies were not able to confirm these findings. ${ }^{18-20}$ In 1952 during the first neuropathological conference in Rome, most neuropathologists agreed that no neuropathomorphology of schizophrenia exists. Thus, psychiatric disorders were considered to be functional psychoses with neurotransmitter changes and no neuropathological basis. In the 1970s, after the publication of enlarged ventricles in brains of schizophrenia patients by the first computer tomographic study, ${ }^{21}$ there was a revival of post-mortem studies in psychiatric disorders such as schizophrenia and affective disorders. ${ }^{22,23}$ These data led to the conviction that psychiatric disorders are brain diseases.

However, both the etiology and pathophysiology of psychiatric disorders are elusive and not well understood. ${ }^{24}$ In-vivo MRI investigations of the brain point to dysfunction in distinct brain regions and neuronal networks, but cannot elucidate subtle neuropathological changes or alterations at the molecular level. Post-mortem research in recent decades using improved technology, such as statistical morphometric and molecular biology techniques ${ }^{25}$ as well as computerassisted quantification techniques which can be applied to the human brain, are causing an increased demand for post-mortem tissue for research. However, modern brain banks face the challenge of declining autopsy rates in all affluent countries. ${ }^{26,27}$ Additionally, such brain banks must meet certain criteria, such as standardized tissue handling and collection of clinical data, which again should enable the comparison of data from different laboratories.

The following paper presents modern techniques of post-mortem investigation in human brains, along with a selective literature review of recent post-mortem findings in psychiatric disorders of interest such as bipolar and unipolar affective disorders as well as schizophrenia. Studies were selected according to the primary field of relevance and whether the results were replicated elsewhere in the literature. Then, demands on modern brain banking are described, such as ethical considerations, clinical work-up, preparation techniques and the organization of a brain bank. Finally the value of modern brain banking for investigations of psychiatric disorders is assessed.

\section{Frequently used standardized techniques in post-mor- tem investigations}

\section{Structural methods}

Stereological investigations represent some of the best validated morphological methods, and they allow for the assessment of the area and volume of a defined brain structure such as different brain regions, subregions or cell types. Moreover, total cell numbers and volumes as well as their distance in a defined structure can be investigated. With the rater blinded to diagnosis, total counts are obtained by the optical fractionator method ${ }^{28}$ using a stereological workstation, consisting of a modified light microscope, Uplan Apo objectives (1,5x, 20x, 50x oil, 100x oil), a motorized specimen stage for automatic sampling, an electronic microcator, a CCD color video camera, PCs with frame grabber boards, stereology software and a television screen monitor. Boundaries of layers and regions are traced on video images displayed on the computer and calculated using Cavalieri's principle. Cell numbers are estimated with the optical fractionator. ${ }^{28-30}$ In addition to histological staining methods, immunohistochemical staining of cellular proteins allows for quantitative differentiation of cellular subgroups. Different cells (pyramidal neurons, interneurons, oligodendroglia, astrocytes) that come into focus within unbiased virtual counting spaces distributed in a systematic-random fashion throughout the brain regions of interest are counted. Estimated cell numbers per section and estimated total numbers per region are calculated from the numbers of counted cells per section and the corresponding sampling probabilities. Volumes of pyramidal neurons and interneurons are estimated using the nucleator probe of the appropriate software.

Schizophrenia is a devastating brain disorder with unknown etiology. Meta-analyses of structural magnetic resonance imaging (MRI) studies reveal gray matter volume deficits in different brain regions in schizophrenic patients. The affected regions are structures within the medial temporal lobe such as the hippocampus and parahippocampal gyrus (limbic system), the heteromodal association cortices such as the prefrontal and parietal cortices, and the superior temporal 
gyrus. ${ }^{31,32}$ Atrophy rates up to $5-10 \%$ have been described in the frontotemporolimbic network. Moreover, the asymmetry of the temporal and prefrontal cortices has been reported to be disturbed in schizophrenia. ${ }^{33-35}$ In schizophrenic patients, positron emission tomography (PET) studies reveal dysfunction of the cortico-cerebellar-thalamic-cortical neuronal circuit which contributes to "cognitive dysmetria," i.e., impaired cognition and other symptoms of the disease. ${ }^{36}$ The small amount of tissue volume reduction in schizophrenia patients suggests that some cellular subfractions within these structures might be lost, reduced in volume or have an altered ratio between different cell types (e.g., neuron to glia ratio). Only post-mortem studies at the microscopic level are able to clarify which cells are disturbed and contribute to the findings described above. Limbic structures may be disconnected from both the prefrontal and temporal cortices in schizophrenia. This may be due to disturbances of the microcircuitry in subsets of neurons and glial cells in the laminar organization of glutamatergic pyramidal neurons and GABAergic interneurons, in concert with oligodendroglia and astroglia in cortical and limbic regions.

A recent post-mortem study of hippocampal grey matter using a gray-level-index (GLI) showed no cytoarchitectural alterations, suggesting no changes in the neuronal perikaryaneuropil ratio. ${ }^{37}$ Earlier quantitative studies In the hippocampus and entorhinal cortex described reduced glial cells as well as unchanged neuron-glia ratios. ${ }^{38-40}$ According to these findings, astrogliosis has not been detected in schizophrenia. ${ }^{41,42}$ The entorhinal cortex is closely connected to the hippocampal formation, linking cortical areas to the hippocampus. ${ }^{43}$ In the entorhinal cortex, abnormalities in the positioning of neuronal clusters (pre-alpha-cells) have been reported and support the hypothesis of migrational disturbances in schizophrenia, ${ }^{6,44,45}$ while other studies have not confirmed these findings. ${ }^{46-48}$ Additionally, in the entorhinal cortex, an immunohistochemical study demonstrated decreased density of tyrosine-hydroxylase labelled axons, pointing to alterations in the dopaminergic system ${ }^{47}$ However, the number and volume of neurons in pre-alpha-cell clusters or other layers of the entorhinal cortex remain unknown. The density of interneurons has also been reported to be decreased in CA2. ${ }^{49}$ Additionally, neurons have been shown to be smaller in schizophrenic patients. ${ }^{50}$ However, two-dimensional cell counting in only a few sections, without consideration of the total hippocampus volume, may have some methodological limitations through the influence of volume differences (e.g., mediated by neuropil degeneration) and tissue shrinkage due to fixation procedures. Two stereological estimates of total cell number reported no differences in the hippocampus of schizophrenic patients. However, one study investigated only the total numbers of neurons, ${ }^{51}$ whereas the subdivision of parvalbumin-positive interneurons has been reported to be decreased. ${ }^{52}$ The second study also did not differentiate between different cell types, and included schizophrenic as well as schizoaffective patients. ${ }^{53}$

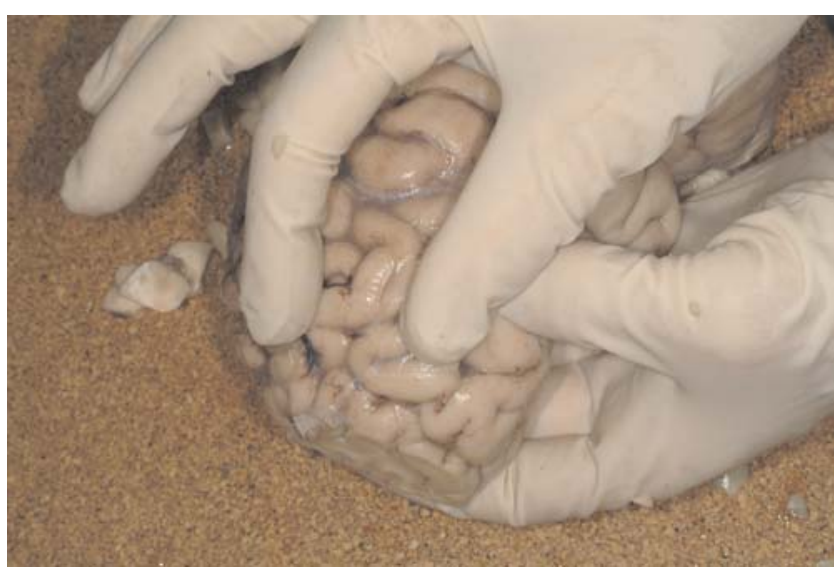

Figure 1- Dissection of the prefrontal cortex (BA46).

In the prefrontal cortex BA (Brodmann area) 10 and BA 9 , no change and an increase of GLI, respectively, points to a circumscribed disturbance of cytoarchitecture was found in schizophrenia. ${ }^{54,55}$ Along these lines, neuronal density has been reported to be increased in BA9. ${ }^{56,57}$ In this region in layer III, pyramidal neurons and neuronal cells showed reduced somal size. ${ }^{58,59}$ Astrocyte density has been reported to be decreased in layer V. ${ }^{58}$ A stereological study of total cell numbers described decreased numbers of oligodendrocytes in layer III of BA9 in schizophrenia. ${ }^{60,61}$ Stereological studies of the anterior cingulate cortex (BA24) measuring the total number of neurons and glial cells reported a reduced number of glial cells and a reduced volume of pyramidal cells in schizophrenia. ${ }^{62,63}$

On the cellular level, the densities of parvalbumineimmunoreactive varicosities in the middle layer of the prefrontal cortex in schizophrenia patients were lower, sug-

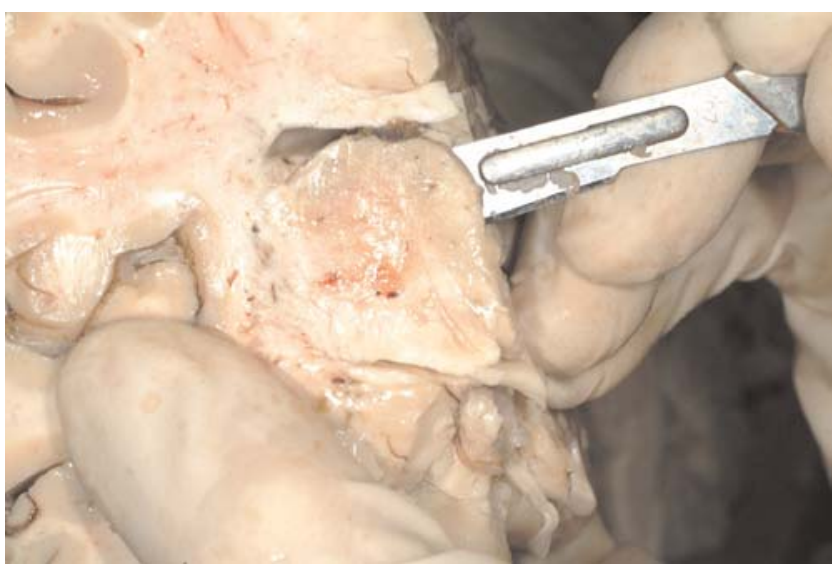

Figure 2 - Dissection of the thalamus (mediodorsal nucleus). 
gesting fewer projections from the thalamus to the prefrontal cortex. ${ }^{64}$ Post-mortem findings of reduced volume, neuron number, and size of the entire thalamus, ${ }^{65}$ mediodorsal nucleus and the pulvinar and ventral posterior thalamic nuclei ${ }^{66,67}$ support the hypothesis of disturbed function and disconnection of different thalamic nuclei in schizophrenia.

Most schizophrenia patients investigated in post-mortem studies were treated with antipsychotic medication such as haloperidol and clozapine for decades. In an animal study, we demonstrated that an increase of total hippocampal volume after chronic haloperidol treatment was not associated with alterations of stereologically measured neurogenesis. ${ }^{68}$ In the striatum of rats, haloperidol treatment induced larger volumes after one month of treatment. This enlargement was associated with vacuous chewing movements, an animal paradigm for tardive dyskinesia. ${ }^{69}$ Additionally, volumetric MRI studies in schizophrenic patients showed an enlargement of the nucleus caudatus after chronic haloperidol treatment and a subsequent volume reduction after treatment with clozapine. ${ }^{70}$

The hippocampus is also a key structure affected in the neurobiology of depression. ${ }^{71-73}$ However, structural magnetic resonance imaging (MRI) studies of the hippocampus in patients with depression show conflicting results, probably due to antidepressant treatment. A recent MRI study of drug-free depressive patients showed a reduced hippocampal volume, especially on the left side. ${ }^{74}$ However, the hippocampus in affective disorders has not yet been studied using stereological techniques. In the entorhinal cortex of patients with bipolar disorder, the total number of parvalbumin-immunoreactive interneurons was decreased. ${ }^{75}$ In major depression, the number of GABAergic neurons were reduced in the prefrontal cortex, ${ }^{76}$ whereas in bipolar disorder, calretinin-stained neurons showed an increased density. ${ }^{77}$ In a densitometry study of the prefrontal cortex, neuronal and glial cell density as well as neuronal size were reduced in depression. ${ }^{78}$ In a stereological study of the orbitofrontal cortex, neuronal size was reduced in layer I in bipolar disorder and in layer 3 in major depressive disorder without an alteration of the cell number. ${ }^{79}$ In bipolar disorder, major depressive disorder and schizophrenia, neuronal density was increased while neuronal size was reduced in the anterior cingulate cortex, indicating similar pathophysiological conditions between these mental illnesses. ${ }^{80}$ In the paraventricular nucleus of the hypothalamus, a stereological post-mortem study reported a significant reduction of neuronal number in major depression and bipolar disorder. ${ }^{81}$ Thus, further structural investigations in affective disorders are warranted to define the affected cell populations in these disorders.

\section{Gene expression studies}

Altered patterns of gene expression (mRNA) are implicated in the pathophysiology of schizophrenia, depression and bipolar disorders. ${ }^{71,82,83}$ The advantage of cDNA microarrays is the ability to simultaneously examine thousands of expressed genes of potential interest, without a hypothesis. Other new molecular techniques include subtractive hybridization ${ }^{84}$, serial analysis of gene expression (SAGE) ${ }^{85}$ and differential display of mRNA. ${ }^{86}$ However, microarray data often require confirmation by other molecular biological techniques, such as reverse transcription-polymerase chain reaction (RT-PCR) and in-situ hybridization, which has the advantage of the ability to delineate anatomically defined structures ${ }^{87}$ Since the brain is not only organized in functionally different regions and circuits, but also in a large variety of cell types (e.g., macro- and microneurons, oligodendrocytes, astrocytes and microglia), which express different fractions of the human transcriptome, large variations in mRNA expression levels are expected. New methods such as laser capture microdissection, fluorescence activated cell sorting (FACS) and single-cell RT-PCR with RNA amplification ${ }^{88-90}$ are promising in showing characteristic alterations of small cell populations. In the thalamus, for example, laser capture dissection of subnuclei permitted the evaluation of gene expression differences in the thalamus of schizophrenic patients. ${ }^{91}$

The nosologic distinction between schizophrenia and bipolar disorder, which is also known as manic-depressive disorder, is an area of ongoing controversy, since both disorders share psychotic and affective symptoms as well as response to antipsychotic treatment. ${ }^{92}$ Accordingly, DNA microarray studies show the same up- or downregulation of genes. Furthermore, mitochondrial dysfunction has been shown in the brain samples of schizophrenia ${ }^{93-97}$ and bipolar disorder patients. ${ }^{96,98,99}$ Mitochondria produce energy, and a failure in energy metabolism has been hypothesized in these disorders. Additionally, oligodendrocyte dysfunction has been hypothesized in schizophrenia, ${ }^{60}$ i.e., downregulation of oligodendrocyte-related mRNAs has been reported in schizophrenia. ${ }^{96,100-104}$ In schizophrenia, downregulation of genes associated with neurite outgrowth, cytoskeletal proteins or synaptic plasticity are in accordance with the hypothesis of disturbances of microconnectivity ${ }^{97}$ Apart from mitochondri$\mathrm{al}^{105}$ and oligodendrocyte dysfunction, ${ }^{96,106}$ downregulation of genes encoding calcium channels and neurotransmitter receptors has been reported in bipolar disorder, while the expression of heat shock proteins was upregulated. ${ }^{104}$ In major depression, oligodendrocyte proteins, ${ }^{107}$ fibroblast growth factor related genes and glutamate transporters have all been reported to be downregulated. ${ }^{108-110}$ Finally, alterations of the GABAergic system were related to depression and suicide. ${ }^{111}$

\section{Investigations of protein expression}

One limitation of gene expression approaches is their ability to study only the intermediate mRNA molecule. Ad- 
ditionally, protein expression should be examined. However, proteins are also vulnerable to degradation by enzymes during the agonal state and the post-mortem period. Moreover, the functions of gene products (proteins) are often highly dependent on posttranslational modifications such as phosphorylation or glycosylation. ${ }^{112}$ Standard techniques to determine protein levels include Western blotting, 2D polyacrylamide gel electrophoresis (2D-PAGE), chromatographic separation, mass spectrometry and radioligand receptor binding, which also examines the functional state of neurotransmitter receptors. Immunohistochemical techniques using specific antibodies in formalin-fixed, paraffin-embedded material are often performed for in-situ investigations of specific anatomical subregions. Proteomic analysis is performed by two-dimensional gel electrophoresis (2DE) followed by MALDI-TOF/ TOF mass spectrometry. This combination is one of the most potent methods of analyzing the complete proteome; it allows a rapid view of changes in multiple protein extracts. Shotgun proteomics is a new method that can overcome some of the limitations of two-dimensional gel electrophoresis. This allows for the investigation of a greater fraction of expressed proteins and for the evaluation of differential protein expression with higher precision. Quantification of shotgun-generated data is improved by the use of stable isotope labeling of the proteins, which allows for more precise comparison and quantification. ${ }^{113}$ Isotope-Coded Protein Labeling (ICPL) is a method for the accurate quantitative comparative analysis of protein regulation. ${ }^{113}$ ICPL is based on isotope labeling of free amino groups in intact proteins. After the modification, the heavy and light isotope labeled proteins are digested and analyzed by liquid chromatography (LC) followed by tandem mass spectrometry (MS/MS). Relative quantification of differential protein expression is based on the comparison of the peak intensities of the heavy- and light-labeled peptides from the mass spectra.

In accordance with gene expression studies, proteins of the mitochondrial pathway have been shown to be altered in schizophrenia, bipolar and depressive disorders, ${ }^{95,114}$ while there is no consensus on the direction of the expression changes. In bipolar disorder and schizophrenia, reduced expression of cytoskeletal proteins has been reported..$^{95,114}$ In addition to these pathways, proteins related to oxidative stress, synaptic function and signaling were altered. ${ }^{115}$ Moreover, proteins involved in gene transcription, protein and RNA chaperoning and cellular homeostasis have been shown to be downregulated in schizophrenia and upregulated in bipolar disorder. ${ }^{116}$ Other immunohistochemical studies show downregulated oligodendrocyte-related proteins in the gray matter of patients with schizophrenia, ${ }^{117,118}$ as well as synaptic proteins in the frontal cortex and hippocampus in schizophrenia and affective disorder. ${ }^{119-122}$ Contrastingly, neural stem cell proliferation was reduced in the dentate gyrus of the hippocampus in schizophrenic but not in depressive patients. ${ }^{123}$ Immunohistochemical investigation of the protein expression of the candidate gene neuregulin- 1 in schizophrenia ${ }^{7}$ revealed a decreased density of neuregulin1 -alpha splice variant expressing cells. Further proteomic and immunohistochemical studies are warranted to identify alterations of proteins which are related to specific metabolic pathways and cell systems in psychiatric disorders.

\section{Ethical issues and brain bank organization}

There are a number of ethical issues involved in the implementation and ongoing activities of a brain bank. Patients with severe psychiatric illnesses such as chronic schizophrenia have caregivers and are not able to appreciate all the consequences of consent in research purposes. For this reason, relatives should be informed if the patient gives his written consent before death in a donor program, and the caregiver should also provide his written consent. A physician should document that the patient has been able to understand the content of the agreement. Donor programs have the advantage of performing prospective standardized diagnostic tests, psychopathological and neuropsychological examinations and relating this information to data obtained from neurobiological measurements.

To obtain the relatives' consent, it is essential to provide them with an informational brochure about the research purposes of the brain bank as well as its organization. It is important that relatives are able to refuse consent at any time, that data protection and anonymization are declared, and that relatives are able to exempt the medical staff from professional discretion for the analysis of medical records and clinical data. If there are no relatives, autopsies for research purposes should not be carried out, since the legal position is not clear.

In our psychiatric institute, a psychiatrist is informed by the (neuro)-pathologist of an appropriate case before autopsy. He/she then calls the relatives and asks for oral consent and requests clinical information on the deceased. It is also important to organize a hotline where the coordinator of the brain bank can be reached at all times. Once informed of the autopsy, he should immediately try to get oral consent from the deceased's relatives. Then, the brain can be prepared and written consent can be obtained. Brain banks need additional manpower for the distribution of the tissue to researchers and documentation.

\section{Clinical data and data protection}

Information about clinical data can be obtained from 
Table 1 - Neuroanatomical preparation protocol in Brain Net Europe II, brain bank of psychiatric diseases, Göttingen

1. Collect the liquor cerebrospinalis after craniotomy.

2. Divide the fresh, unfixed brain into the two hemispheres, including the brain stem and cerebellum.

3. Put the hemispheres on the medial side to prepare the lateral samples A to L (see sample list table 2) from top to bottom according to the Brodmann-diagram.

4. Put the hemispheres on the lateral side to prepare the medial samples M to PP (table 2) according to the Brodmann-diagram.

5. Cut the brainstem with the cerebellum at the level of the mid brain $0.5 \mathrm{~cm}$ above the substantia nigra and place it aside

6. Cut the hemispheres frontally through the corpora mamillare into an anterior and a posterior part.

7. Take the posterior part and cut a frontal slice $2 \mathrm{~cm}$ behind the corpora mamillare.

8. From the anterior and posterior part as well as the $2 \mathrm{~cm}$ slice, prepare samples Q through TA (basal ganglia, thalamus, hippocampus, nucleus accumbens).

9. As a last step, the brain stem and cerebellar areas will be prepared (sample U until N. Dentatus, table 2).

10. Cut samples from the musculus psoas, m. quadriceps femoris, liver, and abdominal fat for analysis of metabolic syndrome, and take one blood sample for genetic analysis.

relatives, general practitioners, psychiatrists and medical records. Clinical diagnosis should be standardized according to DSM-IV/ICD-10 criteria. It is possible to reconstruct psychiatric diagnoses according to the information obtained using the DSM-IV checklists. ${ }^{124}$ Within Brainnet Europe II, our working group on neuropsychiatric brain banking has developed a consensus on clinical information. ${ }^{1}$ All tissue preparations and medical data will be analyzed using code numbers, which precludes associations between data and individuals. Only the written consent form contains personal data and the names of relatives, and these personal data are stored in a separate location. In case of cancellation of consent, the data are erased. The obtained data are included in a firewalled database with access only available to the authorized brain bank assistant.

\section{Regions of interest and neuropathological preparation}

Most scientists prefer to use frozen tissue for studies of protein expression, RNA expression and receptor binding. However, post-mortem intervals (PMI) should not be longer than 48 hours for these studies. Therefore, in brains with PMI until 48 hours, we decided to collect two frozen samples from each brain region and one formalin-fixed and paraffin-embedded sample for immunohistochemistry and neuropathological staining to exclude Alzheimer-related pathology. Brains with longer PMI should be totally formalinfixed and embedded for morphometry. An example for a neuropathological preparation protocol is given in table 1. Freezing of the samples is carried out in liquid nitrogen-cooled isopentane (n-heptane) to avoid freezing artifacts. Fixation is best in $4 \%$ buffered paraformaldehyde with consecutive paraffin-embedding after several hours. Brain sample $\mathrm{pH}$ is believed to be closely associated with the terminal condition of a patient, such as agonal state. Patients with low $\mathrm{pH}$ brain tissue exhibit a gene expression profile distinct from that seen in patients with higher $\mathrm{pH} .{ }^{125}$ Thus, $\mathrm{pH}$ measurement
Table 2 - Definition of regions of interest in psychiatric disorders according to Brodmann. (Each region: 2 frozen samples and 1 formalin-fixed, paraffin-embedded sample). Numbers represent Brodmann Areas

\begin{tabular}{ll}
\hline A: & 17,18 \\
B: & 39 \\
C: & 10 \\
D: & 9 \\
EE: & 47 \\
E: & 11 \\
F: & 44,45 \\
G: & 46 \\
H: & 38 \\
I: & 22 a = anterior \\
J: & 22 p = posterior \\
K: & 21 \\
L: & $1,2,3,4,7$ \\
M: & 32,24 a $=$ anterior \\
N: & 23,31 p = posterior \\
O: & Corpus callosum \\
P: & 20 \\
PP: & $28 / 34$ \\
Q: & Thalamus: mediodorsal \\
QX: & Thalamus: medial Pulvinar \\
QY: & Thalamus anterior region \\
RX: & N. caudatus dorsalis \\
RY: & N. caudatus ventromedialis \\
S: & Putamen \\
T: & Globus pallidus \\
TT: & Substantia Nigra \\
TX: & Capsula interna ventralis \\
TY: & Capsula interna dorsalis \\
TT: & Hippocamus \\
TA: N. accumbens \\
U: & Pons-Basis rostral \\
V: & Pons, caudal \\
W: & Medulla oblongata rostral \\
X: & Medulla oblongata caudal \\
Y: & Spinal cord \\
Cerebellum-Vermis Lous. anterior \\
Cerebellum, Vermis, Lobus medialis \\
Cerebellum, Hemisphere, Lobus posterior \\
Cerebellum Nucleus dentatus \\
\hline
\end{tabular}


is an important way to define this confounding variable in post-mortem tissue. Both hemispheres should be considered in psychiatric cases, because of laterality changes in several brain regions. ${ }^{35} \mathrm{~A}$ detailed list of regions according to the atlas of Brodmann ${ }^{126}$ is given in table 2.

Neuropathological findings in psychiatric cases such as plaques and tangles are common, and should be diagnosed carefully to eliminate confounding factors which may influence data related to the neuropathology of psychiatric disorders. ${ }^{127,128}$ Late-onset psychiatric symptoms such as depression, hallucinations and delusions are common even in patients at the early stages of Lewy body dementia, Alzheimer's disease, Progressive Supranuclear Palsy and Corticobasal Degeneration, ${ }^{129-132}$ and may lead to misdiagnosed cases in a brain bank. ${ }^{133}$ International standard criteria should be followed regarding clinical and neuropathological diagnosis of these dementias. ${ }^{129,134}$ In addition to patients with clinically assessed dementia, patients with schizophrenia and depression may also exhibit Alzheimer's and Parkinson's related neuropathological alterations in their brains, since these changes may precede clinical symptoms by many years. ${ }^{135}$

In summary, modern brain banking is indispensable for neurobiological investigations on mechanisms on the structural, cellular and molecular (mRNA, protein) levels. However, the neurobiological origins of the detected alterations are undetermined. Further studies in post-mortem brains, animal models and cell cultures are required to elucidate the influence of candidate genes and environmental factors during brain development. A growing number of studies identifying candidate genes in mental disorders ${ }^{136,137}$ demonstrate the necessity of genotyping brains of psychiatric patients in order to elucidate the relationship between gene and protein expression and risk genotypes. Finally, in animal models, the interaction between genetic and environmental risk factors, both of physical and psychological origin, must be investigated.

\section{REFERENCES}

1. Schmitt A, Bauer M, Heinsen H, Feiden W, Falkai P, Alafuzoff I, et al. How a neuropsychiatric brain bank should be run: a consensus paper of Brainnet Europe II. J Neural Transm. 2007;114:527-37.

2. Nestler EJ, Barrot M, DiLeone RJ, Eisch AJ, Gold SJ, Monteggia LM. Neurobiology of depression. Neuron. 2002;34:13-25.

3. Ravid R, Van Zwieten EJ, Swaab DF. Brain banking and the human hypothalamus--factors to match for, pitfalls and potentials. Prog Brain Res. 1992;93:83-95.

4. Ravid R, Swaab DF. The Netherlands brain bank--a clinico-pathological link in aging and dementia research. J Neural Transm Suppl. 1993;39:43-53.
5. Kretzschmar HA, Neumann M. [Neuropathological diagnosis of neurodegenerative and dementia diseases]. Pathologe. 2000;21:364-74.

6. Kovalenko S, Bergmann A, Schneider-Axmann T, Ovary I, Majtenyi $\mathrm{K}$, Havas L, et al. Regio entorhinalis in schizophrenia: more evidence for migrational disturbances and suggestions for a new biological hypothesis. Pharmacopsychiatry. 2003;36 Suppl 3:S158-161.

7. Bertram I, Bernstein HG, Lendeckel U, Bukowska A, Dobrowolny $\mathrm{H}$, Keilhoff $\mathrm{G}$, et al. Immunohistochemical evidence for impaired neuregulin-1 signaling in the prefrontal cortex in schizophrenia and in unipolar depression. Ann N Y Acad Sci. 2007;1096:147-56. 
8. Alafuzoff I, Pikkarainen M, Al-Sarraj S, Arzberger T, Bell J, Bodi I, et al. Interlaboratory comparison of assessments of Alzheimer disease-related lesions: a study of the BrainNet Europe Consortium. J Neuropathol Exp Neurol. 2006;65:40-57.

9. Torrey EF, Webster M, Knable M, Johnston N, Yolken RH. The stanley foundation brain collection and neuropathology consortium. Schizophr Res. 2000;44:151-5.

10. Chambers JS, Thomas D, Saland L, Neve RL, Perrone-Bizzozero NI. Growth-associated protein 43 (GAP-43) and synaptophysin alterations in the dentate gyrus of patients with schizophrenia. Prog Neuropsychopharmacol Biol Psychiatry. 2004;29:283-90.

11. Abdolmaleky HM, Cheng KH, Russo A, Smith CL, Faraone SV, Wilcox $\mathrm{M}$, et al. Hypermethylation of the reelin (RELN) promoter in the brain of schizophrenic patients: a preliminary report. Am J Med Genet B Neuropsychiatr Genet. 2005;134:60-6.

12. Haroutunian V, Katsel P, Dracheva S, Stewart DG, Davis KL. Variations in oligodendrocyte-related gene expression across multiple cortical regions: implications for the pathophysiology of schizophrenia. Int $\mathbf{J}$ Neuropsychopharmacol. 2007;10:565-73.

13. Haroutunian V, Pickett J. Autism brain tissue banking. Brain Pathol. 2007; 17:412-21.

14. Grinberg LT, Ferretti RE, Farfel JM, Leite R, Pasqualucci CA, Rosemberg S, et al. Brain bank of the Brazilian aging brain study group - a milestone reached and more than 1,600 collected brains. Cell and tissue banking. 2007;8:151-62

15. Alzheimer A. Contributions to the pathological anatomy of the cerebral cortex and the anatomical basis of some psychoses. Monatsschrift für Psychiatrie und Neurologie 1897;2:1-39.

16. Alzheimer A, Nissl F. Histologie und Histopathologie. Arbeiten über die Grosshirnrinde mit besonderer Berücksichtigung der pathologischen Anatomie der Geisteskrankheiten. 1921.

17. Wernicke C. Grundriss der Psychiatrie in klinischen Vorlesungen. Thieme. 1900

18. Lewis FT. The significance of the term hippocampus. Journal of Comparative Neurology. 1923;35:213-30.

19. Peters RA. Pyruvate oxidase in brain: Co-carboxylase. Biochem J. 1937;31:2240-6.

20. Dunlap CB. Dementia praecox. Am J Psychiatry. 1924;80:403-21.

21. Johnstone EC, Crow TJ, Frith CD, Husband J, Kreel L. Cerebral ventricular size and cognitive impairment in chronic schizophrenia. Lancet. 1976;2:924-6.

22. Kovelman JA, Scheibel AB. A neurohistological correlate of schizophrenia. Biol Psychiatry. 1984;12:1601-21.

23. Bogerts B, Meertz E, Schonfeldt-Bausch R. Basal ganglia and limbic system pathology in schizophrenia. A morphometric study of brain volume and shrinkage. Arch Gen Psychiatry. 1985;42:84-91.

24. Harrison PJ, Owen MJ. Genes for schizophrenia? Recent findings and their pathophysiological implications. Lancet. 2003;36:417-9.
25. Johnston-Wilson NL, Bouton CM, Pevsner J, Breen JJ, Torrey EF, Yolken RH. Emerging technologies for large-scale screening of human tissues and fluids in the study of severe psychiatric disease. Int J Neuropsychopharmacol. 2001;4:83-92.

26. Burton JL, Underwood J. Clinical, educational, and epidemiological value of autopsy. Lancet. 2007;369:1471-80.

27. O'Grady G. Death of the teaching autopsy. BMJ. 2003;327:802-3.

28. Schmitz C, Hof PR. Design-based stereology in neuroscience. Neuroscience. 2005;130:813-31.

29. Schmitz B, Hoehn-Berlage M, Kerskens CM, Bottiger BW, Hossmann KA. Recovery of the rodent brain after cardiac arrest: a functional MRI study. Magn Reson Med. 1998;39:783-8.

30. Schmitz C, Hof PR. Recommendations for straightforward and rigorous methods of counting neurons based on a computer simulation approach. J Chem Neuroanat. 2000;20:93-114.

31. Wright IC, Rabe-Hesketh S, Woodruff PW, David AS, Murray RM, Bullmore ET. Meta-analysis of regional brain volumes in schizophrenia. Am J Psychiatry. 2000;157:16-25.

32. Shenton ME, Dickey CC, Frumin M, McCarley RW. A review of MRI findings in schizophrenia. Schizophr Res. 2001;49:1-52.

33. Falkai P, Bogerts B, Schneider T, Greve B, Pfeiffer U, Pilz K, et al. Disturbed planum temporale asymmetry in schizophrenia. A quantitative post-mortem study. Schizophr Res. 1995;14:161-76.

34. Falkai P, Honer WG, Alfter D, Schneider-Axmann T, Bussfeld P, Cordes $\mathrm{J}$, et al. The temporal lobe in schizophrenia from uni- and multiply affected families. Neurosci Lett. 2002;325:25-8.

35. Crow TJ. Temporal lobe asymmetries as the key to the etiology of schizophrenia. Schizophr Bull. 1990;16:433-43.

36. Andreasen NC, Nopoulos P, O'Leary DS, Miller DD, Wassink T, Flaum M. Defining the phenotype of schizophrenia: cognitive dysmetria and its neural mechanisms. Biol Psychiatry. 1999;46:908-20.

37. Hurlemann R, Tepest R, Maier W, Falkai P, Vogeley K. Intact hippocampal gray matter in schizophrenia as revealed by automatized image analysis postmortem. Anat Embryol (Berl). 2005;210:513-7.

38. Falkai P, Bogerts B. Cell loss in the hippocampus of schizophrenics. Eur Arch Psychiatry Neurol Sci. 1986;236:154-61.

39. Falkai P, Bogerts B, Rozumek M. Limbic pathology in schizophrenia: the entorhinal region--a morphometric study. Biol Psychiatry. $1988 ; 24: 515-21$

40. Benes FM, Bird ED. An analysis of the arrangement of neurons in the cingulate cortex of schizophrenic patients. Arch Gen Psychiatry. 1987;44:608-16.

41. Falkai P, Honer WG, David S, Bogerts B, Majtenyi C, Bayer TA. No evidence for astrogliosis in brains of schizophrenic patients. A postmortem study. Neuropathol Appl Neurobiol. 1999;25:48-53. 
42. Damadzic R, Bigelow LB, Krimer LS, Goldenson DA, Saunders RC, Kleinman JE, et al. A quantitative immunohistochemical study of astrocytes in the entorhinal cortex in schizophrenia, bipolar disorder and major depression: absence of significant astrocytosis. Brain Res Bull. 2001;55:611-18.

43. Weinberger DR. Cell biology of the hippocampal formation in schizophrenia. Biol Psychiatry. 1999;45:395-402.

44. Falkai P, Schneider-Axmann T, Honer WG. Entorhinal cortex pre-alpha cell clusters in schizophrenia: quantitative evidence of a developmental abnormality. Biol Psychiatry. 2000;47:937-43.

45. Jakob H, Beckmann H. Prenatal developmental disturbances in the limbic allocortex in schizophrenics. J Neural Transm. 1986;65:303-26.

46. Krimer LS, Herman MM, Saunders RC, Boyd JC, Hyde TM, Carter $\mathrm{JM}$, et al. A qualitative and quantitative analysis of the entorhinal cortex in schizophrenia. Cereb Cortex. 1997;7:732-9.

47. Akil M, Edgar CL, Pierri JN, Casali S, Lewis DA. Decreased density of tyrosine hydroxylase-immunoreactive axons in the entorhinal cortex of schizophrenic subjects. Biol Psychiatry. 2000;47:361-70.

48. Bernstein HG, Krell D, Baumann B, Danos P, Falkai P, Diekmann S, et al. Morphometric studies of the entorhinal cortex in neuropsychiatric patients and controls: clusters of heterotopically displaced lamina II neurons are not indicative of schizophrenia. Schizophr Res. 1998;33:125-32.

49. Benes FM, Kwok EW, Vincent SL, Todtenkopf MS. A reduction of nonpyramidal cells in sector CA2 of schizophrenics and manic depressives. Biol Psychiatry. 1998;44:88-97.

50. Zaidel DW, Esiri MM, Harrison PJ. Size, shape, and orientation of neurons in the left and right hippocampus: investigation of normal asymmetries and alterations in schizophrenia. Am J Psychiatry. 1997; $154: 812-8$

51. Heckers S, Heinsen H, Geiger B, Beckmann H. Hippocampal neuron number in schizophrenia. A stereological study. Arch Gen Psychiatry. 1991;48:1002-8

52. Zhang ZJ, Reynolds GP. A selective decrease in the relative density of parvalbumin-immunoreactive neurons in the hippocampus in schizophrenia. Schizophr Res. 2002;55:1-10.

53. Walker MA, Highley JR, Esiri MM, McDonald B, Roberts HC, Evans SP, et al. Estimated neuronal populations and volumes of the hippocampus and its subfields in schizophrenia. Am J Psychiatry. 2002; 159:821-8.

54. Kawasak Y, Vogeley K, Jung V, Tepest R, Hutte H, Schleicher A, et al. Automated image analysis of disturbed cytoarchitecture in Brodmann area 10 in schizophrenia: a post-mortem study. Prog Neuropsychopharmacol Biol Psychiatry. 2000;24:1093-104.

55. Vogeley K, Tepest R, Schneider-Axmann T, Hutte H, Zilles K, Honer WG, et al. Automated image analysis of disturbed cytoarchitecture in Brodmann area 10 in schizophrenia. Schizophr Res. 2003;62:133-40.

56. Selemon LD, Rajkowska G, Goldman-Rakic PS. Abnormally high neuronal density in the schizophrenic cortex. A morphometric analysis of prefrontal area 9 and occipital area 17. Arch Gen Psychiatry. 1995;52:805-18; discussion 819-20.
57. Selemon LD, Mrzljak J, Kleinman JE, Herman MM, GoldmanRakic PS. Regional specificity in the neuropathologic substrates of schizophrenia: a morphometric analysis of Broca's area 44 and area 9. Arch Gen Psychiatry. 2003;60:69-77.

58. Rajkowska G, Miguel-Hidalgo JJ, Makkos Z, Meltzer H, Overholser J, Stockmeier C. Layer-specific reductions in GFAP-reactive astroglia in the dorsolateral prefrontal cortex in schizophrenia. Schizophr Res. 2002; $57: 127-38$.

59. Pierri JN, Volk CL, Auh S, Sampson A, Lewis DA. Decreased somal size of deep layer 3 pyramidal neurons in the prefrontal cortex of subjects with schizophrenia. Arch Gen Psychiatry. 2001;58:466-73.

60. Hof PR, Haroutunian V, Friedrich VL, Jr., Byne W, Buitron C, Perl DP, et al. Loss and altered spatial distribution of oligodendrocytes in the superior frontal gyrus in schizophrenia. Biol Psychiatry. 2003;53:1075-85.

61. Hof PR, Haroutunian V, Copland C, Davis KL, Buxbaum JD. Molecular and cellular evidence for an oligodendrocyte abnormality in schizophrenia. Neurochem Res. 2002;27:1193-200.

62. Bouras C, Kovari E, Hof PR, Riederer BM, Giannakopoulos P. Anterior cingulate cortex pathology in schizophrenia and bipolar disorder. Acta Neuropathol (Berl). 2001;102:373-9.

63. Stark AK, Uylings HB, Sanz-Arigita E, Pakkenberg B. Glial cell loss in the anterior cingulate cortex, a subregion of the prefrontal cortex, in subjects with schizophrenia. Am J Psychiatry. 2004;161:882-8.

64. Lewis DA, Cruz DA, Melchitzky DS, Pierri JN. Lamina-specific deficits in parvalbumin-immunoreactive varicosities in the prefrontal cortex of subjects with schizophrenia: evidence for fewer projections from the thalamus. Am J Psychiatry. 2001;158:1411-22.

65. Pakkenberg B. Pronounced reduction of total neuron number in mediodorsal thalamic nucleus and nucleus accumbens in schizophrenics. Arch Gen Psychiatry. 1990;47:1023-8.

66. Byne W, Buchsbaum MS, Mattiace LA, Hazlett EA, Kemether E, Elhakem SL, et al. Postmortem assessment of thalamic nuclear volumes in subjects with schizophrenia. Am J Psychiatry. 2002;159:59-65.

67. Danos P, Baumann B, Bernstein HG, Stauch R, Krell D, Falkai P, et al. The ventral lateral posterior nucleus of the thalamus in schizophrenia: a post-mortem study. Psychiatry Res. 2002;114:1-9.

68. Schmitt A, Weber S, Jatzko A, Braus DF, Henn FA. Hippocampal volume and cell proliferation after acute and chronic clozapine or haloperidol treatment. J Neural Transm. 2004;111:91-100.

69. Chakos MH, Alvir JM, Woerner MG, Koreen A, Geisler S, Mayerhoff $\mathrm{D}$, et al. Incidence and correlates of tardive dyskinesia in first episode of schizophrenia. Arch Gen Psychiatry. 1996;53:313-9.

70. Chakos MH, Lieberman JA, Alvir J, Bilder R, Ashtari M. Caudate nuclei volumes in schizophrenic patients treated with typical antipsychotics or clozapine. Lancet. 1995;345:456-7.

71. Nestler EJ, Barrot M, DiLeone RJ, Eisch AJ, Gold SJ, Monteggia LM. Neurobiology of depression. Neuron. 2002;34:13-25. 
72. Henn FA, Vollmayr B. Basic pathophysiological mechanisms in depression: what are they and how might they affect the course of the illness? Pharmacopsychiatry. 2004;37 Suppl 2:S152-6.

73. Videbech P, Ravnkilde B. Hippocampal volume and depression: a meta-analysis of MRI studies. Am J Psychiatry. 2004;161:1957-66.

74. Saylam C, Ucerler H, Kitis O, Ozand E, Gonul AS. Reduced hippocampal volume in drug-free depressed patients. Surg Radiol Anat. 2006;28:82-7.

75. Pantazopoulos H, Lange N, Baldessarini RJ, Berretta S. Parvalbumin neurons in the entorhinal cortex of subjects diagnosed with bipolar disorder or schizophrenia. Biol Psychiatry. 2007;61:640-52.

76. Rajkowska G, O’Dwyer G, Teleki Z, Stockmeier CA, MiguelHidalgo JJ. GABAergic neurons immunoreactive for calcium binding proteins are reduced in the prefrontal cortex in major depression. Neuropsychopharmacology. 2007;32:471-82.

77. Sakai T, Oshima A, Nozaki Y, Ida I, Haga C, Akiyama H, et al. Changes in density of calcium-binding-protein-immunoreactive GABAergic neurons in prefrontal cortex in schizophrenia and bipolar disorder. Neuropathology. 2007. Dec 5 [Epub ahead of print].

78. Cotter D, Mackay D, Chana G, Beasley C, Landau S, Everall IP. Reduced neuronal size and glial cell density in area 9 of the dorsolateral prefrontal cortex in subjects with major depressive disorder. Cereb Cortex. 2002;12:386-94

79. Cotter D, Hudson L, Landau S. Evidence for orbitofrontal pathology in bipolar disorder and major depression, but not in schizophrenia. Bipolar disorders. 2005; 7:358-69.

80. Chana G, Landau S, Beasley C, Everall IP, Cotter D. Two-dimensional assessment of cytoarchitecture in the anterior cingulate cortex in major depressive disorder, bipolar disorder, and schizophrenia: evidence for decreased neuronal somal size and increased neuronal density. Biological psychiatry. 2003;53:1086-98.

81. Manaye KF, Lei DL, Tizabi Y, Davila-Garcia MI, Mouton PR, Kelly PH. Selective neuron loss in the paraventricular nucleus of hypothalamus in patients suffering from major depression and bipolar disorder. Journal of neuropathology and experimental neurology. 2005;64:224-9.

82. Tsuji T, Shiozaki A, Kohno R, Yoshizato K, Shimohama S. Proteomic profiling and neurodegeneration in Alzheimer's disease. Neurochem Res. 2002;27:1245-53.

83. Akbarian S, Sucher NJ, Bradley D, Tafazzoli A, Trinh D, Hetrick WP, et al. Selective alterations in gene expression for NMDA receptor subunits in prefrontal cortex of schizophrenics. J Neurosci. 1996;16:19-30.

84. Sagerstrom CG, Sun BI, Sive HL. Subtractive cloning: past, present, and future. Annu Rev Biochem. 1997;66:751-83.

85. Velculescu VE, Zhang L, Vogelstein B, Kinzler KW. Serial analysis of gene expression. Science. 1995;270:484-7.

86. Liang P, Pardee AB. Differential display of eukaryotic messenger RNA by means of the polymerase chain reaction. Science. 1992;257:967-71.

87. Marcotte ER, Srivastava LK, Quirion R. DNA microarrays in neuropsychopharmacology. Trends Pharmacol Sci. 2001;22:426-36.
88. Eberwine J. Single-cell molecular biology. Nat Neurosci. 2001;4 Suppl:1155-6.

89. Ginsberg SD, Che S. RNA amplification in brain tissues. Neurochem Res. 2002;27:981-92.

90. Kamme F, Salunga R, Yu J, Tran DT, Zhu J, Luo L, et al. Single-cell microarray analysis in hippocampus CA1: demonstration and validation of cellular heterogeneity. J Neurosci. 2003;23:3607-15.

91. Byne W, Dracheva S, Chin B, Schmeidler JM, Davis KL, Haroutunian V. Schizophrenia and sex associated differences in the expression of neuronal and oligodendrocyte-specific genes in individual thalamic nuclei. Schizophr Res. 2008;98:118-28.

92. Boteva K, Lieberman J. Reconsidering the classification of schizophrenia and manic depressive illness--a critical analysis and new conceptual model. World J Biol Psychiatry. 2003;4:81-92.

93. Ben-Shachar D, Laifenfeld D. Mitochondria, synaptic plasticity, and schizophrenia. International review of neurobiology. 2004;59:273-96.

94. Middleton FA, Mirnics K, Pierri JN, Lewis DA, Levitt P. Gene expression profiling reveals alterations of specific metabolic pathways in schizophrenia. J Neurosci. 2002;22:2718-29.

95. Prabakaran S, Swatton JE, Ryan MM, Huffaker SJ, Huang JT, Griffin $\mathrm{JL}$, et al. Mitochondrial dysfunction in schizophrenia: evidence for compromised brain metabolism and oxidative stress. Mol Psychiatry. 2004;9:684-97, 643

96. Iwamoto K, Bundo M, Kato T. Altered expression of mitochondriarelated genes in postmortem brains of patients with bipolar disorder or schizophrenia, as revealed by large-scale DNA microarray analysis. Hum Mol Genet. 2005;14:241-53.

97. Altar CA, Jurata LW, Charles V, Lemire A, Liu P, Bukhman Y, et al. Deficient hippocampal neuron expression of proteasome, ubiquitin, and mitochondrial genes in multiple schizophrenia cohorts. Biol Psychiatry. 2005;58:85-96.

98. Kato T, Kato N. Mitochondrial dysfunction in bipolar disorder. Bipolar disorders. 2000;2(3 Pt 1):180-90.

99. Kato T. Mitochondrial dysfunction in bipolar disorder: from 31P-magnetic resonance spectroscopic findings to their molecular mechanisms. International review of neurobiology. 2005;63:21-40.

100. Hakak Y, Walker JR, Li C, Wong WH, Davis KL, Buxbaum JD, et al. Genome-wide expression analysis reveals dysregulation of myelinationrelated genes in chronic schizophrenia. Proc Natl Acad Sci U S A. 2001;98:4746-51.

101. Aston C, Jiang L, Sokolov BP. Microarray analysis of postmortem temporal cortex from patients with schizophrenia. J Neurosci Res. 2004:77:858-66.

102. Katsel P, Davis KL, Haroutunian V. Variations in myelin and oligodendrocyte-related gene expression across multiple brain regions in schizophrenia: a gene ontology study. Schizophr Res. 2005;79:157-73. 
103. Dracheva S, Davis KL, Chin B, Woo DA, Schmeidler J, Haroutunian $\mathrm{V}$. Myelin-associated mRNA and protein expression deficits in the anterior cingulate cortex and hippocampus in elderly schizophrenia patients. Neurobiol Dis. 2006;21:531-40.

104. Iwamoto K, Kakiuchi C, Bundo M, Ikeda K, Kato T. Molecular characterization of bipolar disorder by comparing gene expression profiles of postmortem brains of major mental disorders. Mol Psychiatry. 2004;9:406-16.

105. Konradi C, Eaton M, MacDonald ML, Walsh J, Benes FM, Heckers S. Molecular evidence for mitochondrial dysfunction in bipolar disorder. Arch Gen Psychiatry. 2004;61:300-8.

106. Tkachev D, Mimmack ML, Ryan MM, Wayland M, Freeman T, Jones $\mathrm{PB}$, et al. Oligodendrocyte dysfunction in schizophrenia and bipolar disorder. Lancet. 2003;362:798-805.

107. Aston C, Jiang L, Sokolov BP. Transcriptional profiling reveals evidence for signaling and oligodendroglial abnormalities in the temporal cortex from patients with major depressive disorder. Mol Psychiatry. 2005; 10:309-22.

108. Evans SJ, Choudary PV, Neal CR, Li JZ, Vawter MP, Tomita H, et al. Dysregulation of the fibroblast growth factor system in major depression. Proc Natl Acad Sci U S A. 2004;101:15506-11.

109. Choudary PV, Molnar M, Evans SJ, Tomita H, Li JZ, Vawter MP, et al. Altered cortical glutamatergic and GABAergic signal transmission with glial involvement in depression. Proc Natl Acad Sci U S A. 2005;102:15653-58.

110. Sequeira A, Gwadry FG, Ffrench-Mullen JM, Canetti L, Gingras Y, Casero RA, Jr., et al. Implication of SSAT by gene expression and genetic variation in suicide and major depression. Arch Gen Psychiatry. 2006;63:35-48.

111. Sequeira A, Klempan T, Canetti L, ffrench-Mullen J, Benkelfat C, Rouleau GA, et al. Patterns of gene expression in the limbic system of suicides with and without major depression. Mol Psychiatry. 2007; 12:640-655.

112. Banks RE, Dunn MJ, Hochstrasser DF, Sanchez JC, Blackstock W, Pappin DJ, et al. Proteomics: new perspectives, new biomedical opportunities. Lancet. 2000;356:1749-56.

113. Schmidt A, Kellermann J, Lottspeich F. A novel strategy for quantitative proteomics using isotope-coded protein labels. Proteomics. 2005;5:4-15.

114. Beasley CL, Pennington K, Behan A, Wait R, Dunn MJ, Cotter D. Proteomic analysis of the anterior cingulate cortex in the major psychiatric disorders: Evidence for disease-associated changes. Proteomics. 2006;6:3414-25.

115. Clark D, Dedova I, Cordwell S, Matsumoto I. A proteome analysis of the anterior cingulate cortex gray matter in schizophrenia. Mol Psychiatry. 2006;11:459-70.

116. Novikova SI, He F, Cutrufello NJ, Lidow MS. Identification of protein biomarkers for schizophrenia and bipolar disorder in the postmortem prefrontal cortex using SELDI-TOF-MS ProteinChip profiling combined with MALDI-TOF-PSD-MS analysis. Neurobiol Dis. 2006;23:61-76.
117. Honer WG, Falkai P, Chen C, Arango V, Mann JJ, Dwork AJ. Synaptic and plasticity-associated proteins in anterior frontal cortex in severe mental illness. Neuroscience. 1999;91:1247-55.

118. Flynn SW, Lang DJ, Mackay AL, Goghari V, Vavasour IM, Whittall KP, et al. Abnormalities of myelination in schizophrenia detected in vivo with MRI, and post-mortem with analysis of oligodendrocyte proteins. Mol Psychiatry. 2003;8:811-20.

119. Sawada K, Young CE, Barr AM, Longworth K, Takahashi S, Arango $\mathrm{V}$, et al. Altered immunoreactivity of complexin protein in prefrontal cortex in severe mental illness. Mol Psychiatry. 2002;7:484-92.

120. Sawada K, Barr AM, Nakamura M, Arima K, Young CE, Dwork AJ, et al. Hippocampal complexin proteins and cognitive dysfunction in schizophrenia. Arch Gen Psychiatry. 2005;62:263-72.

121. Honer WG, Falkai P, Bayer TA, Xie J, Hu L, Li HY, et al. Abnormalities of SNARE mechanism proteins in anterior frontal cortex in severe mental illness. Cereb Cortex. 2002;12(4):12:349-356.

122. Fatemi SH, Earle JA, Stary JM, Lee S, Sedgewick J. Altered levels of the synaptosomal associated protein SNAP-25 in hippocampus of subjects with mood disorders and schizophrenia. Neuroreport. 2001;12:3257-62.

123. Reif A, Fritzen S, Finger M, Strobel A, Lauer M, Schmitt A, et al. Neural stem cell proliferation is decreased in schizophrenia, but not in depression. Mol Psychiatry. 2006;11:514-22.

124. Hiller W, Dichtl G, Hecht H, Hundt W, von Zerssen D. An empirical comparison of diagnoses and reliabilities in ICD-10 and DSM-III-R. Eur Arch Psychiatry Clin Neurosci. 1993;242:209-17.

125. Li JZ, Vawter MP, Walsh DM, Tomita H, Evans SJ, Choudary PV, et al. Systematic changes in gene expression in postmortem human brains associated with tissue $\mathrm{pH}$ and terminal medical conditions. Hum Mol Genet. 2004;13:609-16.

126. Brodmann K. Vergleichende Lokalisationslehre der Großhirnrinde. Barth. 1925.

127. Thal DR, Rub U, Orantes M, Braak H. Phases of A beta-deposition in the human brain and its relevance for the development of AD. Neurology. 2002;58:1791-1800.

128. Braak H, Braak E. Neuropathological stageing of Alzheimer-related changes. Acta Neuropathol. 1991;82:239-59.

129. Kertesz A, McMonagle P, Blair M, Davidson W, Munoz DG. The evolution and pathology of frontotemporal dementia. Brain. 2005; 128:1996-2005.

130. Jellinger K, Riederer P, Tomonaga M. Progressive supranuclear palsy: clinico-pathological and biochemical studies. J Neural Transm Suppl. 1980:111-128.

131. Ballard C, Holmes C, McKeith I, Neill D, O’Brien J, Cairns N, et al. Psychiatric morbidity in dementia with Lewy bodies: a prospective clinical and neuropathological comparative study with Alzheimer's disease. Am J Psychiatry. 1999;156:1039-45.

132. Sweet RA, Hamilton RL, Butters MA, Mulsant BH, Pollock BG, Lewis DA, et al. Neuropathologic correlates of late-onset major depression. Neuropsychopharmacology. 2004;29:2242-50. 
133. Mendez MF, Mastri AR, Sung JH, Zander BA, Frey WH, 2nd. Neuropathologically confirmed Alzheimer's disease: clinical diagnoses in 394 cases. J Geriatr Psychiatry Neurol. 1991;4:26-29.

134. Ferrer I, Barrachina M, Puig B. Anti-tau phospho-specific Ser262 antibody recognizes a variety of abnormal hyper-phosphorylated tau deposits in tauopathies including Pick bodies and argyrophilic grains. Acta Neuropathol. 2002;104:658-64.
135. Ritchie K, Lovestone S. The dementias. Lancet. 2002;360:1759-66.

136. Farmer A, Elkin A, McGuffin P. The genetics of bipolar affective disorder. Current opinion in psychiatry. 2007;20:8-12.

137. Harrison PJ, Weinberger DR. Schizophrenia genes, gene expression, and neuropathology: on the matter of their convergence. Mol Psychiatry. 2005;10:40-68; image 45. 